\title{
Statyba
}

\section{MULTI-CRITERION ASSESSMENT OF ECONOMIC AND FINANCIAL CONDITION OF SELECTED CONSTRUCTION COMPANIES IN POLAND}

\section{W. Meszek \& T. Thiel}

To cite this article: W. Meszek \& T. Thiel (2001) MULTI-CRITERION ASSESSMENT OF ECONOMIC AND FINANCIAL CONDITION OF SELECTED CONSTRUCTION COMPANIES IN POLAND, Statyba, 7:4, 314-320, DOI: 10.1080/13921525.2001.10531742

To link to this article: https://doi.org/10.1080/13921525.2001.10531742

Published online: 30 Jul 2012.

Submit your article to this journal $\llbracket$

Џ Article views: 70

4 Citing articles: 1 View citing articles 준 


\title{
MULTI-CRITERION ASSESSMENT OF ECONOMIC AND FINANCIAL CONDITION OF SELECTED CONSTRUCTION COMPANIES IN POLAND
}

\author{
W. Meszek, T. Thiel \\ Poznań University of Technology
}

\section{Introduction}

Total assessment of economic and financial condition of construction companies is a relatively complex procedure which involves application of a number of indices, and the knowledge of their interrelations and interreactions. In practice, such an assessment is performed by means of a variety of sets of indices, which are often changed and that, in consequence, makes it difficult to draw conclusions and perform assessments. It transpired, on many occasions, that using a relatively big number of indices blurs the image and makes it difficult to reach a final decision.

Due to the existence of the problems indicated above, a number of simplified methods got into the circulation which are not only fit to assess the condition of individual companies, but also to draw comparisons between them. Those methods are based on certain synthetic indices (examples listed in section 2), the usefulness of which has, in many cases, been a subject of many years of research.

There are some contexts, nevertheless, where popular synthetic indices do not meet the expectations of the analyst. This is particularly true about the assessment of a small number of companies which, when ordered according to a given index, present themselves in a different order than expected, often not in keeping with the preferences of the analyst. In such cases, it is important and useful to have an instrument of analysis in hand which, basing on the presupposed order of preference for a selected group of companies, and on known economic and financial parameters (or individual indices) might make it possible to widen the scope of analysis and make it applicable in order to enable broadening of the analysis on a set of any size, according to the preferences of the analyst.
In order to test the appropriateness of results arrived at by means of such an instrument, the authors suggested and used a procedure based on the following:

- ordering of the companies, according to a selected synthetic index,

- choosing a random (small) group of companies, and assuming that the order they are in (basing on the synthetic index used) reflects the analyst preferences,

- analysing the whole group of companies using a multi-criterion approach,

- comparing that order from the point of view of a synthetic index, and from the point of view of multicriterion analysis.

2. Assessment of the economic and financial condition of selected construction companies using the Altman Model

There is a number of indices used in synthetic assessment of the economic and financial condition of companies and organisations, many of which are used in assessing foreseeable bankruptcies.

Those indices are based on groups of selected specific indices, and the final assessment of the economic and financial condition is performed according to one of the following procedures:

a) attaching a set of specific indices to one of the model variants which defines the economic and financial condition of a company, in accordance with a presupposed rating and scale,

b) calculating a synthetic index (as a single value) using weights attached to individual specific indices, and identifying a category resulting from the assumed rating and scale; a set of the defined weights which describe the relationships within the calculation is 
usually referred to as multiple discriminate analysis.

The examples of synthetic indices used in the context of developed market economy, also as a result of positive tests of coherence with real condition of the analysed companies (in a complex approach) and businesses are as follows:

- for procedure (a): the so-called Quick-Test [1],

- for procedure (b): the so-called Simplified Discrimination Analysis Index, Springate's G.L.V. Model, and the Altman Model [2]

In particular, the Altman Model - based on the specific indices listed below - is well known and widely used:

- turnover capital share in the assets index $\left(X_{1}\right)$,

- kept profit share in the assets index $\left(X_{2}\right)$,

- gross profit share (before interest) in the assets index $\left(\mathrm{X}_{3}\right)$,

- market value of shares capital to the value of due payments index $\left(\mathrm{X}_{4}\right)$,

- assets rotation index $\left(\mathrm{X}_{5}\right)$.

With the appropriate function of discrimination, this model takes the following form:

$$
Z=1,2 \cdot X_{1}+1,4 \cdot X_{2}+3,3 \cdot X_{3}+0,6 \cdot X_{4}+1,0 \cdot X_{5} \cdot(1)
$$

Attempts have also been made to modify the indices, taking into consideration the specific Polish context. The J. Gajdka and D. Stos [3] Model has been quite popular as a modification of the Altman Model.

This paper uses the Altman Model, with the reservation of using some more detailed definitions of certain financial categories (for example, of the kept profit, or gross profit before interest) which, in view of Polish book-keeping procedures, might be burdened with lack of precision. In the effect of this reservation, the Altman Model indices have been assumed to be as follows:

$$
\begin{aligned}
& X_{1}=\frac{\text { current assets }- \text { short } \text {-term liabilities }}{\text { assets }} \\
& X_{2}=\frac{\text { net profit }}{\text { assets }} \\
& X_{3}=\frac{\text { operating profit }}{\text { assets }} \\
& X_{4}=\frac{\text { share capital }}{\text { liabilities }}
\end{aligned}
$$

$$
X_{5}=\frac{\text { net revenue from sales }}{\text { assets }}
$$

The Altman Model, in the version presented above, has been used to order (from the viewpoint of their economic and financial condition) a group of 34 Polish building companies listed in the Warsaw Securities Exchange. The process of analysis is presented in Table 1 (the data reflect the condition of the companies as of the end of 1999 [4]). The table also contains the final ranking, based on the Altman Index value.

\section{Application of the selected multi-criterion analy- sis method in the assessment of the economic and financial condition of construction companies}

\subsection{Selection of the method}

In the analysed problem all the criteria in question are of quantitative character. With respect to each criterion, the difference in value for any given pair of variants is crucial for the decision maker. In effect, there is no modelling of preferences with regard to a single criterion which, in turn, means that those are true criteria. Moreover, what is important for the decision maker, is the "distances" occurring in the final assessment between all the variants are compared. Therefore, it has been assumed that the function oriented model will best suit the needs of the decision maker's preferences modelling. This was a basis for choosing the UTA method [5], which is applied to the utility function. Within the method, the comparison of variants and their final ranking boils down to comparing the values attached to individual variants within the framework of the function. The UTA method has been qualified as one of the multi-criterion methods, where compensation logic of aggregation is used in very small extent, and where the final result is arrived at directly, ie basing on the global model of preferences, without using any additional procedures [6].

\subsection{Description of the UTA method [5]}

In the UTA method, it is the additive utility function, which is a special case of a utility function that constitutes the global model of preferences (GMP). The form of the additive function can be recorded as follows:

$$
U(g)=\sum_{i=1}^{n} u_{i}\left(g_{i}\right)
$$


where $n$ is the number of criteria, $g_{i}$ is the assessment of an variant with regard to criterion $i$, and $u_{i}\left(g_{i}\right)$ is the partial utility.

This function must reflect the decision maker's preferences. The UTA method is aimed at finding such a function. The method consists of two phases: a phase of disaggregation and a phase of aggregation. During the disaggregation phase, the additive utility function is constructed (in a normalised form). The decision maker's preferences regarding the selected variants, which themselves become a reference set, constitute the basis of this construction. Applying the preference relation $(\mathrm{P})$, and indifference relation (I), the decision maker defines a complete pre-order on this set which is a reflection of his preferences. Basing on the preorder which has been arrived at, the utility function $\mathrm{U}(\mathrm{g})$ is also designed which will be in keeping with the pre-order. The $U(g)$ function, thanks to the $R=P \cup I$ relation, reflects the complete pre-order in the set of admissible variants. The technique of designing the utility function, which is based on complete pre-order established by the decision maker on a set (sample) of variants, is called ordinal regression. If such a function exists, it can be applied with regard to the whole set of variants and, consequently, arrived at the final ranking of all variants. Using ordinal regression helps to define the additive utility functions which have the maximum concordance with the subjective ordering introduced by the decision maker for the set of referential variants $A^{\prime}$. An additional variable, $\sigma(a) \geq 0$, is introduced for every variant $a$ being part of the reference set, which represents the estimation error when the utility function is defined. The utility function reflecting complete pre-ordering on the set of referential variants $A^{\prime}$ takes the following form:

$$
U^{\prime}(a)=\sum_{i=1}^{n} u_{i}\left[g_{i}(a)\right]+\sigma(a) \quad \text { for all } a \in A^{\prime},
$$

where $a$ is an variant from the set of referential variants, and $A^{\prime}$ is a set of referential variants, while $i$ is a number of criteria describing the problem, $u_{i}\left[g_{i}(a)\right]$ represents partial utility of the $a$ variant from the standpoint of the $i$ criterion, $\sigma(a)$ represents the estimation error for the $a$ variant.

The utility function which is searched for is arrived at by solving a linear programming problem which minimises the sum of estimation errors with regard to individual variants.

The target function represented by the following formula:

$$
\min F=\sum_{a \in A^{\prime}} \sigma(a)
$$

and its limitations have been presented in [5] and [7]. As to the target function represented by formula (9), the limitations are as follows:

- normalisation related to the additive function,

- describing the complete pre-order in the set of referential variants, established by the decision maker,

- related to the assumption of monotone character of preferences with respect to every criterion, and

- related to the requirements of non-negativity of the decision variables.

The limitations listed above guarantee a match of appropriate characteristics for an additive utility function, which is searched for. This function has the following qualities:

- it enables arriving at normalised utility values;

- it is concordant with the decision maker's preferences, defined on the set of referential variants;

- it assures the monotone character of the preferences with respect to every criterion;

- it contains a minimum utility estimation error (itself being a sum of all errors).

It is assumed that function of partial utility is linear in intervals. If this is the case, the functions of partial utilities, which are linear in intervals, must be monotone in character and non-decreasing, and then $\alpha_{i}$, therefore a number of characteristic points (maximum 5) are given for each criterion. The values of assessment in characteristic points for $i$-th criterion, the partial utility for one criterion, and the values of utility for a given variant can be described according to formulae provided in [5], [7].

Due to the number of limitations and variables, the dual problem is solved with relation to the problem presented above. As a result, the optimum function of utility $U^{*}(g)$ is arrived at (in the sense of a minimum of the sum of errors) which constitutes a numerical representation of $\mathrm{R}^{*}$ relation. In order to perform the assessment of concordance and utility of $\mathrm{U}^{*}(\mathrm{~g})$ and $\mathrm{R}^{*}$ relation which it has introduced (estab- 


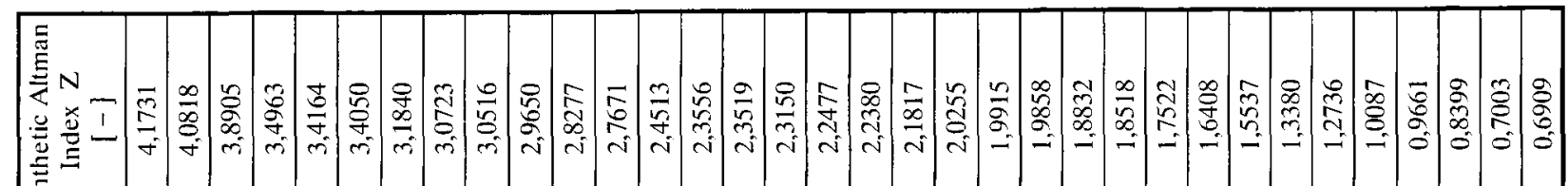
离

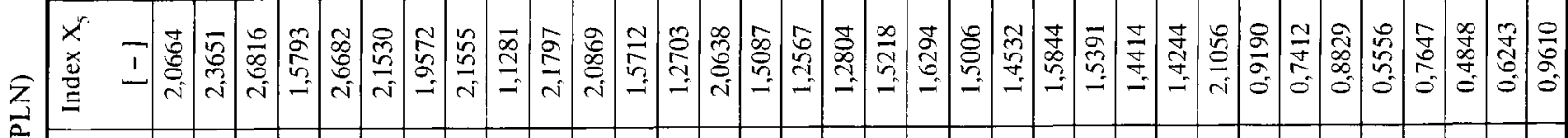

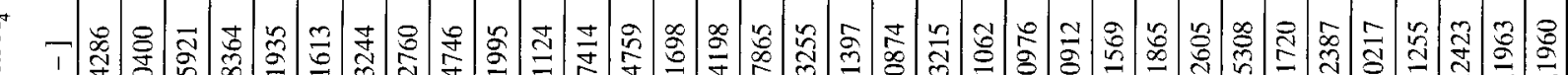

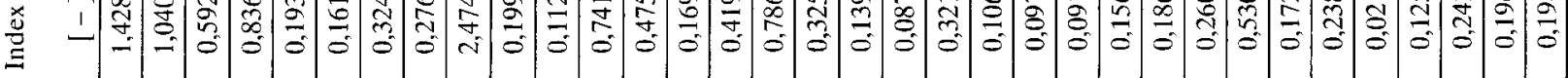

要

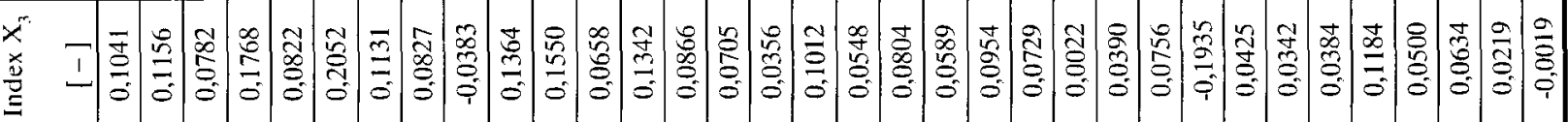

$\bar{\tau}$

紊

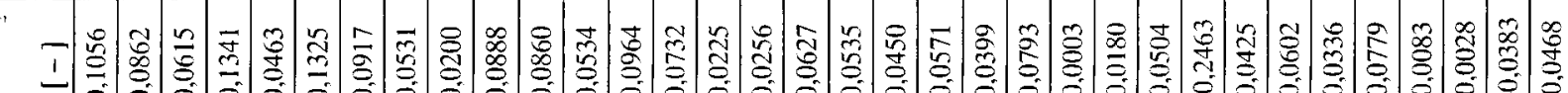
1.

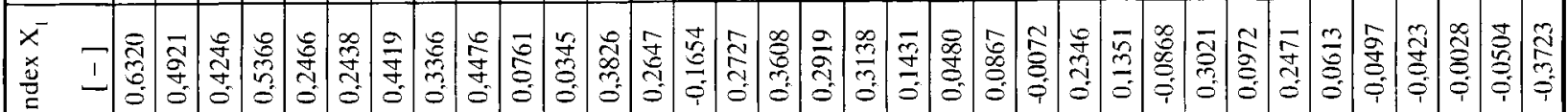

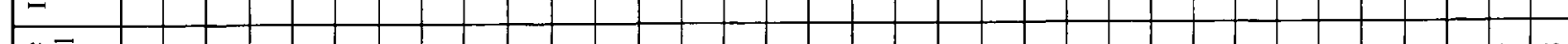

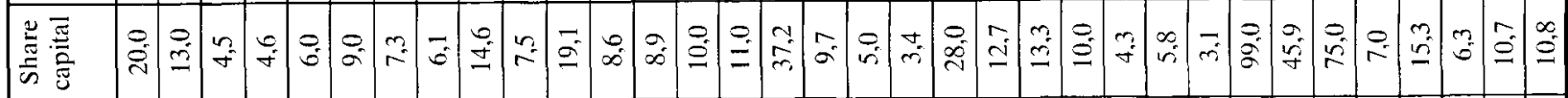
品

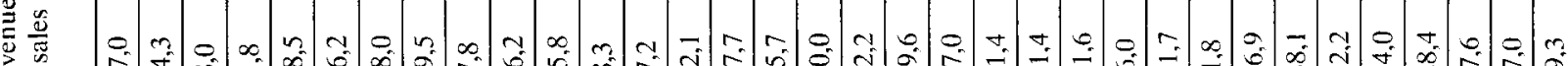

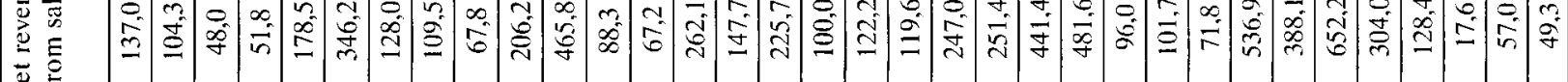
$\frac{2}{\underline{\underline{n}}}$

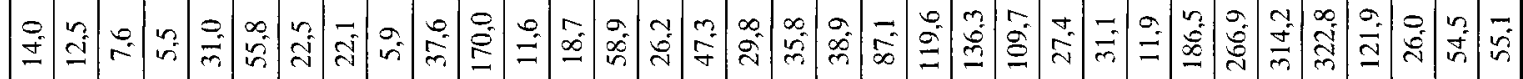

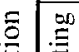

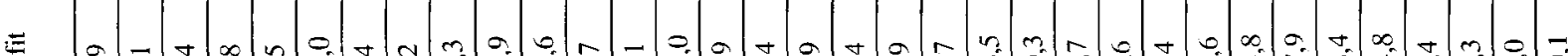

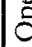

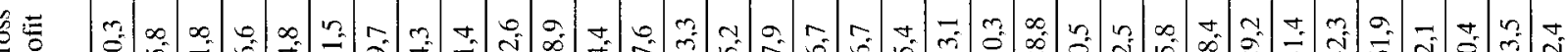

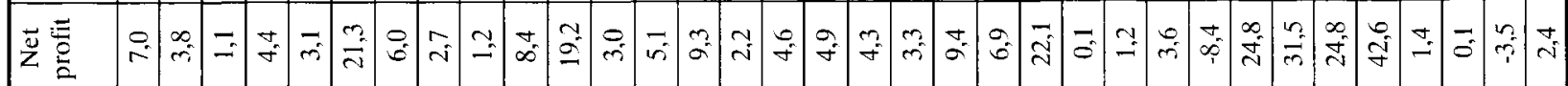

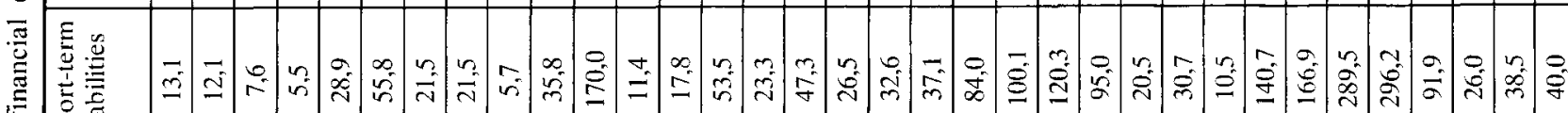
要

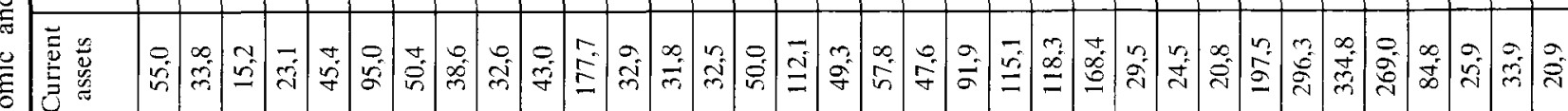

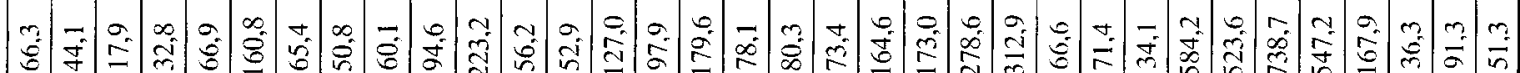

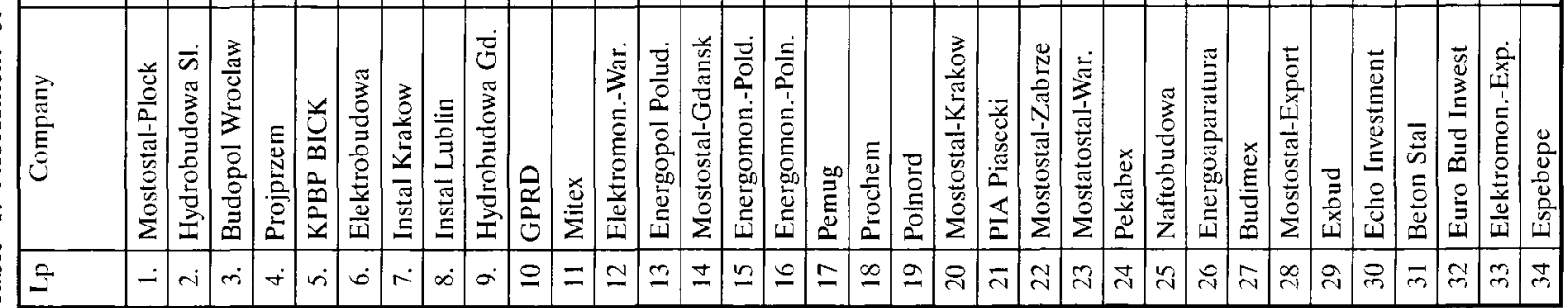


lishing complete pre-order) with $\mathrm{R}$ relation (defined by the decision maker) on the $A^{\prime}$ set, Kendall's coefficient $\tau$ is used

The manner of calculation and application of the index has been presented in [7]. The closer the coefficient to 1 , the better the concordance of the two preorders. If the full concordance occurs between $\mathrm{R}^{*}$ and $\mathrm{R}$ relations, then $\tau=1$ and when $\mathrm{F}^{*}=0$ (the sum of estimation errors is equal to 0 ), it signifies that the identified utility function exactly reflects the decision maker's preferences. In other words, it is in keeping with the initial pre-order (the function is concordant with the pre-order in the sense of Kendall's concordance criterion).

It is precisely such a situation that has been applied in "Prefcalc" [8] and [9], a software developed and applied for the needs of the method which is being discussed, and has been used to perform calculations within the framework of the problem analysed in this paper.

Regarding the utility function, which has been arrived at, the values of partial utilities for particular criteria have been presented (the process ends the disaggregation phase). During the aggregation phase, the decision maker can modify partial utilities values by way of changing their optimums, or at the intermediate points, and changing the number of intervals describing a given partial utility.

\subsection{Information used in UTA method and included in the "Prefcalc" software}

In the framework of co-operation with the "Prefcalc" software, having identified a family of criteria describing a given problem, and having selected a set of variants which should be assessed, the decision maker does the following:

- defines maximum and minimum of the borderlines of values which individual criteria may take;

- with regard to individual criteria, the decision maker gives the number of linear intervals which would characterise the functions of partial utilities for those criteria;

- selects a set of referential variants from all variants assumed to be the basis for the multi-criterion assessment;

- makes the assessment of individual variants taken from the set of referential variants (put into a subjective order by means of the relation of $R=P \cup I$. which would constitute a base for establishing a complete preorder within the set of those variants). The assessment can be carried out according to rank $(1,2,3$, etc.), or according to a ranking scale (the range of values of assessments from 0,01 to 1,00 ), retaining the possibility of accepting an ideal and an anti-ideal variant, or - on the other hand - the possibility of rejecting either of those variants. The ideal variant contains the best ratings for individual criteria, whereas the anti-ideal variant contains the worst ratings for individual criteria, taking all variants into consideration;

- the decision maker can modify the functions of partial utilities for individual criteria (arrived at during the phase of disaggregation) or all previously provided information, or - on the other hand - accept the partial utilities within reach and use the utility function which has been arrived at with respect to the set of all variants (aggregation phase). Applying the function with respect to the whole set of variants makes it possible to arrive at the final ranking of variants according to the decreasing values of total utility defined for each variant.

\section{Results of the calculations}

Within the framework of the analysed problem, the Altman Model indices constitute the criteria of evaluation, while construction companies become the set of variants. It has been assumed that attaching ranks valued at $1,2,3, \ldots, \mathrm{k}$, to individual companies, where $\mathrm{k}$ signifies a number of variants, will be the basis of the assessment. The ideal and anti-ideal variants have been incorporated in the assessment. Moreover, it has been assumed that:

- all criteria would be taken into consideration $\left(\mathrm{X}_{\mathrm{i}}\right.$ indices),

- the functions of partial utilities (for individual indices) will be described by one interval with constant inclination,

- the ranges of variability of values for the accepted criteria will not be altered and, in effect, all variants will be included in the analysis, while minimum and maximum values will be accepted in the calculations on the basis of minimum and maximum values of criteria. 
Following a number of attempts, the decision maker has defined a set of referential variants and assessed them, attaching ranks to those variants (taking into account all the criteria). Eventually, the set of variants included in the assessment consists of 12 construction companies, and the ideal and anti-ideal variants (reflecting the best and the worst performing company among all taken into consideration). The order in which this sample of variants took has been presented below, as well as the values of ranks attached to individual companies-variants is as follows:
1. Ideal
2. Hydrobudowa Slask
3. Projprzem
4. Instal Krakow
5. GPRD
6. Elektromontaz - Warszawa
7. Energopol Poludnie
8. Prochem
9. Pekabex
10. Budimex
11. Exbud
12. Beton Stal
13. Espebepe
14. Anty-ideal

Basing on the calculations performed by means of the "Prefcalc" software, the accepted ordering of variants turned out to be concordant with at least one utility function. As a result of a suggestion put forward by the software regarding a definite utility function, the partial utilities values were arrived at with regard to individual criteria. The partial utilities values change in a linear mode within the whole range of variability of values. For the smallest value they are equal to 0 for each criterion, and with regard to the largest value, they are as follows:

- for criterion 1: 0,19 (for the maximum value $=0,63$ ); - for criterion 2: 0,08 (for the maximum value $=0,13$ ); - for criterion 3: 0,24 (for the maximum value $=0,21$ ); - for criterion 4: 0,18 (for the maximum value $=2,48$ ); - for criterion 5: 0,31 (for the maximum value $=2,68$ ).

Applying the additive utility function for partial utilities assumed to be and approved of as what they are, made it possible to define the value of this function for each of all analysed building companies, and to arrive at the final ranking of the companies, starting from the best performing one, to the worst performing one. The positions and the values of utility function with regard to all companies have been presented in Table 2.

Table 2. The final ranking of construction companies arrived at as the result of application of the UTA method

\begin{tabular}{|c|c|c|}
\hline $\begin{array}{c}\text { Position held } \\
\text { in the ranking }\end{array}$ & Construction company & $\begin{array}{c}\begin{array}{c}\text { Value of utility } \\
\text { function }\end{array} \\
\end{array}$ \\
\hline 1 & Ideal & 1.00 \\
\hline 2 & Mostostal-Plock & 0.77 \\
\hline 3 & ${ }^{*}$ Hydrobudowa Slask & 0.76 \\
\hline 4 & Budopol Wroclaw & 0.73 \\
\hline 5 & *Projprzem & 0.69 \\
\hline 6 & Elektrobudowa & 0.68 \\
\hline 7 & KPBP BICK & 0.66 \\
\hline 8 & *Instal Krakow & 0.64 \\
\hline 9 & Instal Lublin & 0,62 \\
\hline 10 & *GPRD & 0,60 \\
\hline 11 & Mitex & 0,59 \\
\hline 12 & Hydrobudowa Gdansk & 0,58 \\
\hline 13 & *Elektromontaz-Warszawa & 0,57 \\
\hline 14 & *Energopol Poludnie & 0,53 \\
\hline 15 & Mostostal-Gdansk & 0,51 \\
\hline 15 & Energomontaz-Poludnie & 0,51 \\
\hline 17 & Energomontaz-Polnoc & 0,50 \\
\hline 17 & Pemug & 0,50 \\
\hline 17 & *Prochem & 0,50 \\
\hline 20 & Polnord & 0,49 \\
\hline 21 & Mostostal-Krakow & 0,46 \\
\hline 21 & PIA Piasecki & 0,46 \\
\hline 21 & Mostostal-Zabrze & 0,46 \\
\hline 24 & Mostatostal-Warszawa & 0,44 \\
\hline 24 & *Pekabex & 0,44 \\
\hline 26 & Naftobudowa & 0,42 \\
\hline 27 & *Budimex & 0,39 \\
\hline 28 & Energoaparatura & 0,38 \\
\hline 29 & Mostostal-Export & 0,36 \\
\hline 30 & "Exbud & 0,35 \\
\hline 31 & Echo Investment & 0,32 \\
\hline 32 & " Beton Stal & 0,31 \\
\hline 33 & Euro Bud Inwest & 0,29 \\
\hline 34 & Elektromontaz-Export & 0,27 \\
\hline 35 & *Espebepe & 0,25 \\
\hline 36 & Anty-ideal & 0,00 \\
\hline
\end{tabular}

*signifies the companies selected by the decision maker which constitute a set of referential variants whose order in the final ranking is the same as in the ordering assumed by the decision maker. 
The final ranking of all construction companies with respect to the assessment of their economic and financial condition which is presented in Table 2 has been judged as the most credible. It is also quite close (nearly identical) to the final result arrived at using the synthetic Altman Index (see section 2, Table 1).

It must be mentioned that both the modifications of values of individual partial utility functions, and the changes in the number of companies and accepting other companies into the set of referential variants, resulted in arriving at final rankings of all assessed companies, which were radically different from the ranking presented in Table 2 and from the results arrived at basing on Altman's synthetic index.

\section{Conclusions}

As a result of the development of institutions and mechanisms of market economy, the demand for analyses and assessments of economic and financial condition of companies grows rapidly. Therefore, simplified methods of assessment become attractive tools, which enable undertaking economic decisions.

A comparison of results arrived at after the application of both methods validates the statement that multi-criterion analysis methods may be useful in assessing economic and financial condition of companies and organisations. Moreover, those methods make room, in every individual case, for taking the decision maker's preferences into account. Therefore, the fact that the procedure described in section 1 is appropriate, has been confirmed.

\section{References}

1. E. Mączyńska. Ocena kondycji przedsiębiorstwa // Życie Gospodarcze, Nr 38, 1994.

2. M. Zdyb. Syntetyczna ocena sytuacji finansowej przedsiębiorstwa // Forum Budowlane, Nr 12, 1999.

3. M. Zdyb. Controlling kondycji finansowej przedsiębiorstw budowlanych // Forum Budowlane, Nr 9, 2000.

4. Almanach Spółek Giełdowych // PARKIET, VIII Edycja Wiosna '2000, Warszawa, 2000.

5. E. Jacquet-Lagreze, J. Siskos. Assessing a set of additive utility functions for multicriteria decision making, the UTA method // European Journal of Operational Research, Vol 10, $\mathrm{Nr} 2,1982$, p. 151-164.

6. T. Thiel. Metodyczne aspekty wielokryterialnego wspomagania decyzji w inżynierii produkcji budowlanej. Dissertation, Wydzial Budownictwa, Architektury i Inżynierii Środowiska / Politechnika Poznańska, Poznań, 1996.

7. R. Słowiński. Metoda konstrukcji addytywnej funkcji użyteczności i jej zastosowanie do wielokryterialnego programowania liniowego // Postępy Cybernetyki 8, Nr 4, 1985 , p. $81-91$.

8. E. Jacquet-Lagreze. PREFCALC - Evaluation et decision multicriteres, EURO-DECISION, Paris, 1983.

9. E. Jacquet-Lagreze. Interactive assessment of preferences using holistic judgements: the PREFCALC system // Readings in Multiple Criteria Decision Aid, Bana e Costa C. Ed. Springer-Verlag, Berlin, 1990, p. 335-350.

Iteikta 20010420

\section{EKONOMINIS IR FINANSINIS PASIRINKTU STATY- BOS KOMPANIJŲ LENKIJOJE DAUGIAKRITERINIS IVERTINIMAS}

\section{W. Meszek, T. Thiel}

\section{S a n tra u k a}

Pateikti du statybos kompaniju Lenkijoje ivertinimo metodai. Taikant pirmaji metodą naudojamas kompleksinis Altmano indeksas. Pasirinktoms kompanijoms buvo nustatyta šio indekso reikšmè. Vertinant antruoju metodu, pasiūlytu autoriaus, pritaikyta naudingumo funkcija (metodas UTA). Šis metodas yra vienas iš daugiakriteriniụ analizès metodụ.

Aprašomas UTA metodas, pradinè informacija ir duomenu bazè, panaudota Prefcalc programiniam aprūpinimui. Pateikti programos skaičiavimo rezultatai. Jie palyginti naudojant statybos kompaniju rangavimo abiem metodais reikšmes.

Wieslaw MESZEK. Doctor, C.E., Asssistant Professor. Institute of Structural Engineering. Poznań University of Technology. Piotrowo 5, 60-965 Poznań, Poland.

PhD (1990). Research interests: organisation, planning and realisation of building processes, construction management, games theory, decision-making and operations research in building production engineering.

Tomasz THIEL. Doctor, C.E., Assistant Professor. Institute of Structural Engineering. Poznań University of Technology. Piotrowo 5, 60-965 Poznań, Poland. E-mail: tomasz.thiel@put.poznan.pl.

PhD (1997). Research interests: organisation, planning and realisation of building processes, construction management, decision-making, decision aiding and operations research in building production engineering. 